\title{
Variability of indices of macronutrient availability in soils at different spatial scales along an elevation transect in tropical moist forests (NE Ecuador)
}

\author{
Malte Unger • Christoph Leuschner • \\ Jürgen Homeier
}

Received: 29 October 2009 / Accepted: 8 July 2010 / Published online: 30 July 2010

(C) The Author(s) 2010. This article is published with open access at Springerlink.com

\begin{abstract}
The availability of key plant nutrients may change with elevation in tropical mountains due to altitudinal gradients in temperature and moisture which affect pedogenesis and nutrient cycling. In a transect from upper lowland to montane forests in NE Ecuador, we tested the hypotheses that (1) the availability of $\mathrm{P}$ is low in low-elevation forests but increases upslope, while the availability of $\mathrm{N}$ is relatively high at low elevations but decreases with elevation, and (2) increasing amounts of calcium, magnesium and potassium are stored on top of the soil with progressive humus accumulation toward higher elevations, likely to improve nutrient availability. In each 20 plots in undisturbed natural forest at 500 , 1000, 1500 and 2000 ma.s.l., we measured in situ N net mineralization and nitrification rate $\left(\mathrm{N}_{\mathrm{NM}}\right.$ and $\mathrm{N}_{\mathrm{NI}}$, buried bag method), plant-available phosphorus $\left(\mathrm{P}_{\mathrm{a}}\right.$, resin-bag method), and salt-exchangeable calcium, potassium and magnesium concentrations $\left(\mathrm{Ca}_{\mathrm{ex}}, \mathrm{K}_{\mathrm{ex}}\right.$, $\left.\mathrm{Mg}_{\text {ex }}\right)$ in the organic and mineral topsoils. $\mathrm{N}_{\mathrm{NM}}$ and $\mathrm{N}_{\mathrm{NI}}$, and the $\mathrm{Ca}_{\mathrm{ex}}, \mathrm{K}_{\mathrm{ex}}$ and $\mathrm{Mg}_{\mathrm{ex}}$ concentrations were much more variable at the plot level than across the four elevations, while $\mathrm{P}_{\mathrm{a}}$ varied equally at small and large spatial scales. $\mathrm{P}_{\mathrm{a}}$ increased more than 10 fold from 500 to $2000 \mathrm{~m}$. The net release of nitrate dominated
\end{abstract}

Responsible Editor: Harry Olde Venterink.

M. Unger $\cdot$ C. Leuschner $(\bowtie) \cdot J$. Homeier

Plant Ecology, University of Göttingen,

Untere Karspüle 2,

37073 Göttingen, Germany

e-mail: cleusch@gwdg.de over ammonium at all elevations. While mass-related $\mathrm{N}_{\mathrm{NM}}$ and $\mathrm{N}_{\mathrm{NI}}$ rates and also organic matter $\mathrm{C} / \mathrm{N}$ ratio in the topsoil remained invariant along the slope, $\mathrm{N}_{\mathrm{NM}}$ and $\mathrm{N}_{\mathrm{NI}}$ rates per ground area decreased by about $40 \%$ from 500 to $2000 \mathrm{~m}$. Thus, the $\mathrm{N}_{\mathrm{NM}} / \mathrm{P}_{\mathrm{a}}$ ratio decreased markedly with elevation proving our first hypothesis. In support of the second hypothesis, the pools of $\mathrm{Ca}_{\mathrm{ex}}$, $\mathrm{Mg}_{\mathrm{ex}}$ and $\mathrm{K}_{\mathrm{ex}}$ in the organic layers increased with elevation, demonstrating the key role that organic topsoil horizons are playing for forest nutrition at high elevations. We suggest that the large difference in $\mathrm{N}$ versus $\mathrm{P}$ availability of tropical (upper) lowland and montane forests is likely to be a key factor influencing the species composition and productivity along tropical mountain slopes.

Keywords Exchangeable cations $\cdot$ Humus accumulation · Nitrogen mineralization $\cdot$ Nutrient limitation · Plant-available phosphorus · Tropical montane forest
Abbreviations
$\mathrm{N}_{\mathrm{NM}} \mathrm{N}$ net mineralization rate
$\mathrm{N}_{\mathrm{NI}}$ net nitrification rate
$\mathrm{P}_{\mathrm{a}} \quad$ plant-available phosphorus

\section{Introduction}

A decrease of tree height with increasing elevation is probably the most obvious characteristic of tropical 
forests when climbing from the mountain foot to the summits (Moser et al. 2008). However, alterations in tree structure are often associated with, and may partly be caused by, distinct changes in soil properties and humus morphology from lowland to upper montane forests (Bruijnzeel and Proctor 1995; Schawe et al. 2007). There is a vital debate as to whether the elevational temperature decrease, or other factors such as increases in precipitation, soil moisture, soil acidity, litter phenol content, or in the extent of nutrient limitation of plant growth, are key factors causing the progressive accumulation of organic matter on top of the soil along tropical mountain slopes (Grubb 1977; Tanner 1981; Jordan and Herreira 1981; Vitousek 1984; Vitousek and Sanford 1986; Schuur 2001; Schawe et al. 2007; Benner et al. 2010). Already Jenny (1980) proposed that a decreasing decomposition rate with increasing elevation is the direct cause of humus accumulation at higher altitudes. Lower decomposition rates are linked to reduced nutrient mineralization and element cycling rates per unit soil organic matter and thus may induce nutrient shortage at higher elevations (Bruijnzeel and Proctor 1995; Iost et al. 2008). However, increasing amounts of organic matter stored on top of the soil lead to larger nutrient stocks in the topsoil (Edwards and Grubb 1977) with the potential to provide additional rooting space and nutrient sources. Various authors have pointed out that nutrients released from the organic layer play an important role for plant nutrition in tropical montane forests (Grubb 1977; Edwards and Grubb 1977, 1982; Edwards 1982; Cuevas and Medina 1986, 1988; Grubb 1995; Kaufmann et al. 1998).

There is substantial evidence, mostly from foliar nutrient analyses, that tree growth in many tropical lowland forests is primarily limited by phosphorus (P), while plant-available nitrogen $(\mathrm{N})$ seems to be relatively abundant (e.g. Vitousek 1984; Vitousek and Sandford 1986; Cuevas and Medina 1988; Tiessen et al. 1994). According to the conceptual model of pedogenesis and nutrient availability of Walker and Syers (1976), N supply should be poor in young soils and $\mathrm{N}$ fixation from the atmosphere an important process, whereas $\mathrm{P}$ should become progressively unavailable during pedogenesis. Similar to calcium $(\mathrm{Ca})$, magnesium $(\mathrm{Mg})$ and potassium $(\mathrm{K}), \mathrm{P}$ is supplied to the soil solution by weathering of parent material, and it is often present in plant-available form in very low concentrations in old, highly weathered soils (Grubb 1977; Edwards and Grubb 1977, 1982; Edwards 1982; Kitayama et al. 2004), where sorption plays an important role (Walker and Syers, 1976; Vitousek, 1984; Olander and Vitousek 2004). Tropical montane forests most often grow on younger or rejuvenated soils, where $\mathrm{N}$ thus may be short in supply, while P limitation of growth should be of lower importance than in lowland forests which typically grow on older soils. Nutrient addition experiments in tropical montane forests (Jamaica: Tanner et al. 1990; Hawaii: Harrington et al. 2001; Colombia: Cavelier et al. 2000; Venezuela: Tanner et al. 1992) in fact provided evidence that $\mathrm{N}$ is a major proximate limiting nutrient to plant growth in the sense of Vitousek et al. (2010).

Transect studies across tropical mountain slopes may provide valuable information on elevational changes in nutrient availability (e.g. Grieve et al. 1990; Bruijnzeel et al. 1993; Schawe et al. 2007; Wilcke et al. 2008) which may help to identify ultimate limiting nutrients to plant growth at different elevations because they may not be detected in fertilization experiments with a rather short duration. In this study, we searched for altitudinal effects on plant nutrient availability in tropical upper lowland $(500 \mathrm{~m})$ to montane forests $(2000 \mathrm{~m})$ with a focus on the five quantitatively most important plant nutrient elements, N, P, Ca, Mg and $\mathrm{K}$. We tested the hypotheses that (1) the availability of $P$ is low in low-elevation forest soils, but increases with elevation, while the availability of $\mathrm{N}$ is relatively high at low elevations but decreases upslope, and (2) with progressive humus accumulation on top of the soil, increasing amounts of $\mathrm{Ca}, \mathrm{Mg}$ and $\mathrm{K}$ are stored in the organic layers toward higher elevations that may improve nutrient availability. Because spatial heterogeneity of soils may be a critical confounding factor of altitudinal transect studies, we investigated a large number of forest plots ( 80 in total) and started with an investigation of the small- and regional-scale variability of soil properties at four elevations (each 20 plots at 500, 1000, 1500 and $2000 \mathrm{~m}$ elevation). We put a special emphasis on the measurement of plantavailable fractions of the five nutrient elements, i.e. in situ measurement of $\mathrm{N}$ net mineralization rate, plant-available $\mathrm{P}$, and salt-exchangeable $\mathrm{Ca}, \mathrm{Mg}$ and $\mathrm{K}$ concentrations at the cation exchangers. As a study area, we choose a moist forest region in NE Ecuador 
which represents the last remaining continuous forest block extending from the foothills to the summits of the east equatorial Andes.

\section{Materials and methods}

Study area

The study was conducted in the Sumaco Biosphere Reserve (SBR) and its close proximity in the province of Napo, NE Ecuador, immediately at the equator. The reserve was established in 2000 and is situated on the eastern slopes of the Andes and their adjacent foothills and includes the Sumaco volcano. The area represents the last remaining altitudinal transect of undisturbed vegetation from the upper lowlands (400 ma.s.1.) to the páramo $(3700 \mathrm{~m})$ in the eastern equatorial Andes, a biodiversity hotspot which harbours probably more than 6000 plant species (Neill and Palacios 1997). The 80 study plots were allocated to four elevation levels $(500,1000,1500$, and $2000 \mathrm{~m}$ ) representing an altitudinal transect of $1500 \mathrm{~m}$ elevational distance (Fig. 1).

The climate varies from moist, hot tropical in the eastern lowland regions to moist, warm subtropical in the higher western reaches. Exact data on annual precipitation in the study region is lacking, but rainfall is likely to exceed $2500 \mathrm{mmyr}^{-1}$ in most parts of the area. The Sumaco volcano and the Cordillera Guacamayos most likely receive more than $4000 \mathrm{mmyr}^{-1}$. Throughout the area, precipitation usually never drops below 100 mmmonth $^{-1}$ (Neill and Jørgensen 1999). Mean annual temperature decreases from approximately $22.9^{\circ} \mathrm{C}$ at $415 \mathrm{~m}$ (Jatun Sacha biological station) to $14.3^{\circ} \mathrm{C}$ at $2015 \mathrm{~m}$ (Sumaco volcano) (own unpublished data).

The eastern slopes of the Ecuadorian Andes (Oriente) consist of two distinct physiogeographic zones, the Oriente basin and the Sub-Andean Zone. In the Oriente, quaternary clastic sediments include a variety of deposits, from lavas and pyroclastics of various grain sizes to colluvial/alluvial materials (piedmont fans) and alluvial fills. The topographically more diverse sub-Andean zone consists of foothills rising to elevations of up to $2000 \mathrm{~m}$, deeply dissected by east-flowing rivers. As a consequence of high rainfall and relatively high temperatures, rates of rock weathering are generally high. The Sub-Andean Zone borders the Cordillera Real and is a back-arc foldthrust belt tectonically associated with the Andes (Baldock 1982).

The geology is variable in the area but not well studied. In most of the region, parent rocks from the Cretaceous dominate, mainly limestone. However, at Volcano Sumaco (basalt) and at Hakuna Matata (granite), volcanic and intrusive rocks, respectively, are present. Slates are found at Cordillera Guacamayos (Sauer 1971).

The soils show a considerable heterogeneity throughout the study region. Most of the excavated profiles at 500 and $1000 \mathrm{~m}$ were classified as Geric Ferralsols according to the World Reference Base for Soil Resources (IUSS Working Group WRB. 2006), while we found a preponderance of Cambisols at the upper study sites (1500 and $2000 \mathrm{~m}$ ).

Following the most recent vegetation classification for Ecuador (Palacios et al. 1999), the studied forests at $500 \mathrm{~m}$ can be classified as evergreen lowland forests, the stands at $1000 \mathrm{~m}$ as evergreen premontane forests, and the upper elevation forests (1500 and $2000 \mathrm{~m}$ ) as evergreen lower montane forests.

At each of the four elevation levels (500, 1000, 1500 and $2000 \mathrm{~m}$ ), three study sites (at $500 \mathrm{~m}: 2$ ) were selected (see Fig. 1) which each included 5 to 12 study plots resulting in 20 plots per elevation level and 80 plots in total.

\section{Soil analysis}

We installed 80 plots of $20 \mathrm{~m} \times 20 \mathrm{~m}$ size at the four different altitudinal levels and marked them permanently. The 80 plots are grouped at 11 sites being 6 to $>70 \mathrm{~km}$ distant to each other (Fig. 1). Each site had a size of about $2 \mathrm{~km} \times 2 \mathrm{~km}$ and harboured forest stands representative for the respective elevation. Typically, each site of $4 \mathrm{~km}^{2}$ size represented the small-scale topographic and pedologic variability in the region. For plot selection, only areas without any kind of visible human or natural disturbance were selected in mature forest stands in order to study a matrix of old-growth stands along elevational and small-scale topographic gradients. The 5 to 12 plots per site were selected at distances to each other of several hundred $\mathrm{m}$ (minimum distance: $100 \mathrm{~m}$ ).

For characterizing important soil chemical properties in the 80 stands, four soil samples were collected 
Fig. 1 Map of the study region in North-eastern Ecuador (Sumaco Biosphere Reserve, SBR) with location of the 11 study sites

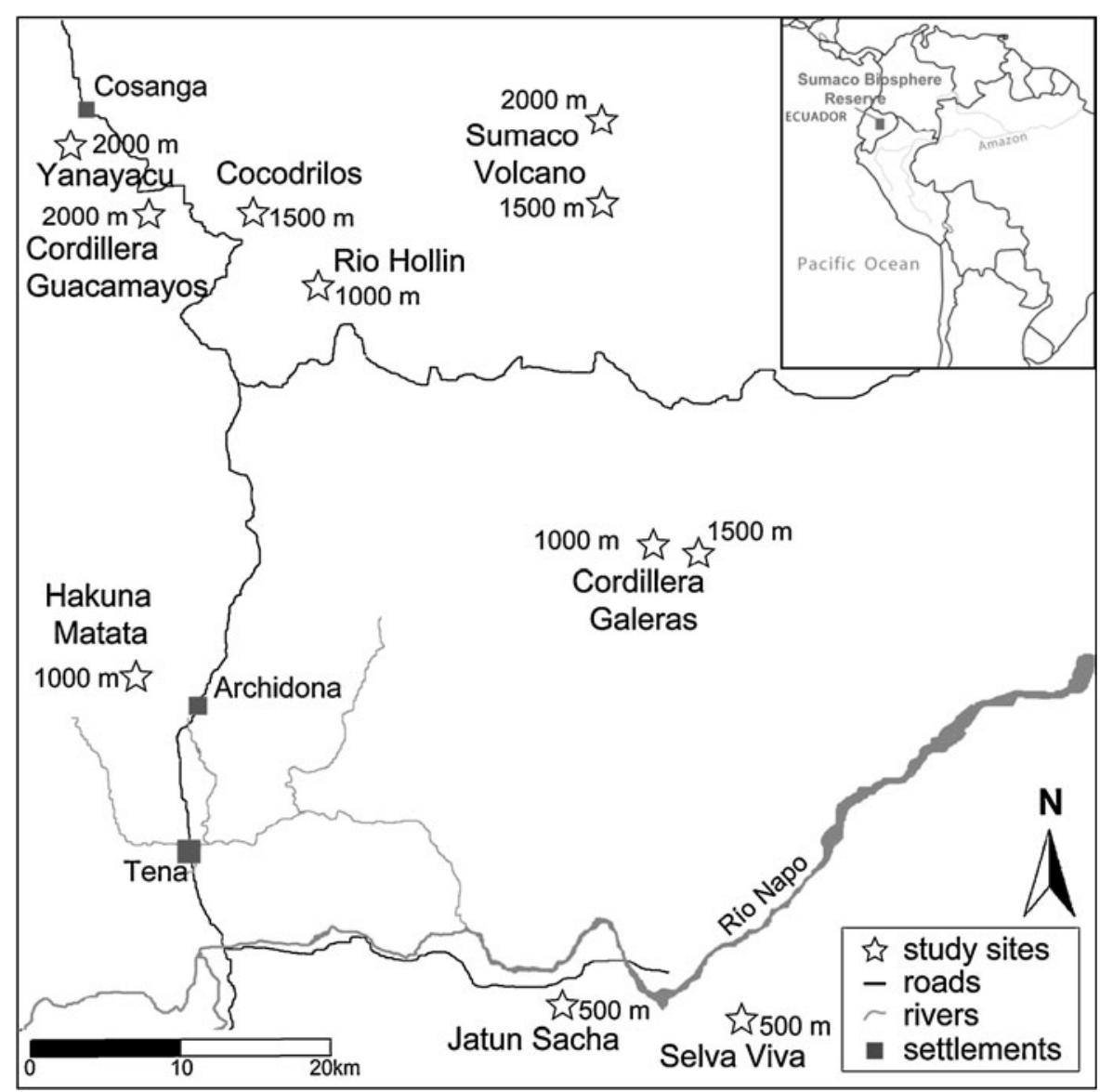

in every plot in the period April to June 2007. We divided the study plots into four equally-sized quadrates of $10 \mathrm{~m} \times 10 \mathrm{~m}$. In the centre of each quadrate, a soil core of $5 \mathrm{~cm}$ diameter and 20-25 cm length was taken. This core was separated into two sections, the organic layer and the top $10 \mathrm{~cm}$ of the mineral soil. The organic layer consists of a mixture of the organic $\mathrm{L}, \mathrm{F}$ and $\mathrm{H}$ horizons; the boundary between the organic $\mathrm{H}$ and the mineral soil Ah horizon was set at about $30 \%$ organic matter content using morphological criteria of the substratum for estimating organic matter content. The upper mineral soil consisted of Aand/or B-horizons with less than $30 \%$ of organic matter content.

The soil samples were stored in polyethylene bags in a refrigerator $\left(5^{\circ} \mathrm{C}\right)$ until transported by air freight to Germany where the analyses were carried out. The fresh soil samples were analyzed for $\mathrm{pH}_{\mathrm{H} 2 \mathrm{O}}$ and $\mathrm{pH}_{\mathrm{KCl}}(1 \mathrm{~N}$ $\mathrm{KCl})$ with a glass electrode according to Jackson (1958); the soil: water ratio was 1:2.5 for the mineral soil and 1:10 for the organic layer soil.
The total concentrations of $\mathrm{C}$ and $\mathrm{N}$ were determined with a $\mathrm{C} / \mathrm{N}$ elemental analyzer (Vario EL III, elementar, Hanau, Germany) in the ground and dried $\left(70^{\circ} \mathrm{C}, 48 \mathrm{~h}\right)$ soil. The concentrations of saltexchangeable cations in the organic layer and in the $0-0.1 \mathrm{~m}$ horizon of the mineral soil were determined by percolating $2.5 \mathrm{~g}$ of air-dried soil with $100 \mathrm{ml}$ $0.2 \mathrm{~N} \mathrm{BaCl}_{2}$ solution for $4 \mathrm{~h}$ (Bower and Wilcox, 1965). The solution concentrations of exchangeable potassium $\left(\mathrm{K}_{\mathrm{ex}}\right)$, magnesium $\left(\mathrm{Mg}_{\mathrm{ex}}\right)$, calcium $\left(\mathrm{Ca}_{\mathrm{ex}}\right)$ and aluminum $\left(\mathrm{Al}_{\mathrm{ex}}\right)$ were analyzed by atomic absorption spectroscopy (Vario 6, Analytic Jena, Germany). The concentration of hydrogen ions at the cation exchangers of the soil was calculated from the observed $\mathrm{pH}$ change during the percolation process.

As an estimate of plant-available phosphorus $\left(\mathrm{P}_{\mathrm{a}}\right), \mathrm{P}$ was extracted by resin bags (Dowex $1 \times 8-50$ ), which were placed for $16 \mathrm{~h}$ in a solution of $1 \mathrm{~g}$ soil material suspended in $30 \mathrm{ml}$ of water (Sibbesen 1977; Bowman and Cole 1978; Agbenin and van Raij 2001). P was 
then re-exchanged by $\mathrm{NaCl}$ and $\mathrm{NaOH}$ solutions and analysed colorimetrically after blue-dyeing (Murphy and Riley 1962). The total P concentration of the organic layer dry mass was determined photometrically with a staining procedure (p-yellow) after digestion of the sample with $65 \% \mathrm{HNO}_{3}$ at $195^{\circ} \mathrm{C}$.

\section{Net $\mathrm{N}$ mineralization and nitrification rates}

Between March and April 2008, eight topsoil samples (soil cores of $5 \mathrm{~cm}$ diameter and $10 \mathrm{~cm}$ length consisting of both organic layer and mineral soil material) were collected in every plot (each two in the center of the four $10 \mathrm{~m} \times 10 \mathrm{~m}$ quadrates) to determine net $\mathrm{N}$ cycling rates. One soil core per quadrate was extracted in the field immediately (see procedure below) for determination of initial concentrations of ammonium and nitrate. Part of the soil from the first core was also used for gravimetric determination of actual water content $\left(105^{\circ} \mathrm{C}, 48 \mathrm{~h}\right.$, dry weight basis) and soil bulk density. The second soil core was placed in a closed polyethylene bag, reburied in the soil at exactly the same spot were it was taken to incubate the material in situ for 8 days and thereafter extracted in the field in the same way as described below. The polyethylene bags permitted a certain exchange of gases but inhibited the passage of water.

Before and after incubation, the $\mathrm{NH}_{4}{ }^{+}-\mathrm{N}$ and $\mathrm{NO}_{3}{ }^{-}-\mathrm{N}$ concentrations of the samples were determined by extracting about $90 \mathrm{~g}$ of a sample in $300 \mathrm{ml}$ of a 0.5 molar $\mathrm{K}_{2} \mathrm{SO}_{4}$ solution. The extracts were shaken thoroughly for $2 \mathrm{~h}$, allowed to equilibrate for another $2 \mathrm{~h}$, and filtered through Whatman no. 2 filter paper (Whatman International, Maidstone, Kent, UK). The filter paper was rinsed beforehand with about $50 \mathrm{ml}$ blank $0.5 \mathrm{M}$ potassium sulfite solution. We added $1 \mathrm{ml}$ chloroform to each filtrate for retarding microbial growth (Robertson 1984). All extracts were frozen directly after the filtration (Arnold et al. 2008), transferred to Germany by plane and analyzed. In all buried soil samples, there was no appreciable loss of water during the incubation period.

The concentrations of $\mathrm{NH}_{4}{ }^{+}$and $\mathrm{NO}_{3}{ }^{-}$were measured colorimetrically by continuous flow injection (Cenco/Skalar Instuments, Breda, Netherlands) in which $\mathrm{NH}_{4}^{+}$is quantified using the Berthelot reaction method (Skalar Method 155-000) and $\mathrm{NO}_{3}{ }^{-}$is determined using the copper-cadmium reduction method (Skalar Method 461-000). Daily N net mineralization rate $\left(\mathrm{N}_{\mathrm{NM}}\right)$ per soil dry mass was calculated by subtracting the initial concentration of $\mathrm{NH}_{4}^{+}$plus $\mathrm{NO}_{3}{ }^{-}$from that after incubation divided by the days of incubation. Net nitrification rate $\left(\mathrm{N}_{\mathrm{NI}}\right)$ was calculated as the difference between initial and final $\mathrm{NO}_{3}{ }^{-}$ concentration. Positive $\mathrm{N}$-figures indicate gain from the soil, negative ones $\mathrm{N}$ consumption or immobilization of $\mathrm{N}$ by biotic or abiotic processes in the soil. Standrelated $\mathrm{N}$ net mineralization and net nitrification rates were calculated by multiplying the mass-specific $\mathrm{N}_{\mathrm{NM}^{-}}$ and $\mathrm{N}_{\mathrm{NI}^{-}}$-rates with the bulk density of the soil and the depth $(10 \mathrm{~cm})$ of the respective soil sample, thus yielding soil volume- and ground area-related net release rates (unit: molNha ${ }^{-1} \mathrm{~d}^{-1}$ ). The results of the soil analyses are presented either in the Figs. 2, 3 and 4 or in Table 2.

Data analysis

Linear regression analyses were applied to identify significant relationships between elevation as independent variable and soil chemical parameters. All regressions were calculated using Xact software (version 8.0; SciLab, Hamburg, Germany). To test for significant differences in nutrient concentrations among the plots of different elevations, nonparametric analyses of variance (Kruskal-Wallis test), combined subsequently with two-sample tests (Wilcoxon $U$ test) and three-factorial analyses of variance for unbalanced data sets (General Linear Models) were conducted using SAS software (version SAS 9.1 for Windows; SAS Institute, Cary, North Carolina, USA). $P<0.05$ was used as the significance level throughout the study.

\section{Results}

Spatial heterogeneity of soil properties

By analyzing soil samples from 320 different locations ( 80 plots with each 4 sampling locations), we were able to characterize the about 20 investigated soil properties in terms of their heterogeneity at different spatial scales. Most soil chemical parameters showed the largest variability at the within-plot level, i.e. over distances of not more than $10 \mathrm{~m}$ (Table 1), while the parameters varied less between different plots, sites (at a given elevation), and between the 
Fig. 2 Soil phosphorus concentrations in the 80 study plots as a function of elevation ( $\mathrm{m}$ above sea level). a concentration of plant available $P$ ( $\mathrm{P}_{\mathrm{a}}$, resin-bag-method) in the organic layer; b concentration of $\mathrm{P}_{\mathrm{a}}$ in the upper mineral soil layer $(0-0.1 \mathrm{~m}), \mathbf{c}$ total $\mathrm{P}$ concentration $\left(\mathrm{P}_{\mathrm{t}}\right)$ in the organic layer. Given are the means of the 20 plots per elevation level; the location of the plots at the each 3 (500 m: 2) study sites is indicated by different symbols. Abbreviations: Jatun Sacha (J.S.), Selva Viva (S.V.), Rio Hollin (R.H.), Hakuna Matata (H.M.), Cordillera Galleras (GA.), Sumaco (SU.),

Cocodrillos (CO.),

Cordillera Galleras (GA.), Sumaco (SU.),

Cordillera Huacamayos

(C.H.), Yanayacu (Y.Y.)

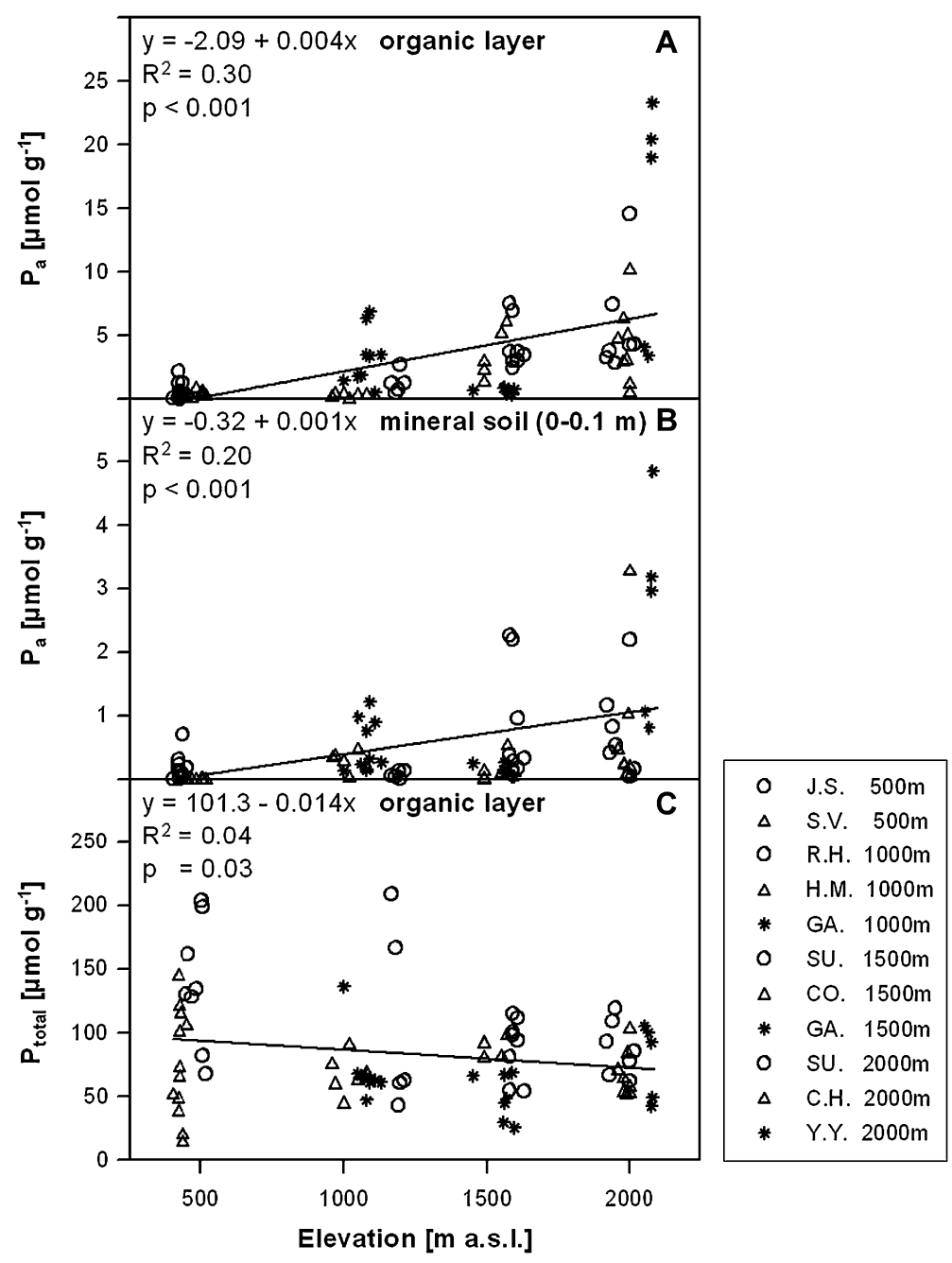

four elevations (e.g. $\mathrm{pH}, \mathrm{C} / \mathrm{N}$ ratio, exchangeable cation concentrations, and $\mathrm{N}$ net mineralization/ nitrification rates). Only a minority of properties varied primarily across elevations while being less variable on a regional and local scale (e.g. depth of organic layer and $\mathrm{N}_{\mathrm{t}}$ concentration). Plant-available $\mathrm{P}$ was the only parameter revealing similar variances at the within-plot, within-site, between-site and acrosselevation levels, while total $\mathrm{P}$ showed largest variation at the within-site (between-plot) and within-plot levels (Table 1).

Soil organic matter and soil acidity

The mean depth of the organic layer (L, F, H horizons) on top of the mineral soil increased about fourfold from $0.16 \mathrm{~m}$ in the plots at $500 \mathrm{~m}$ to
$0.63 \mathrm{~m}$ at 1500 ma.s.l. and remained constant higher up on the slope (Table 2). A significant altitudinal trend was visible despite the considerable spatial heterogeneity of organic layer properties at a given altitude.

The acidity of the organic layer showed a large between-plot variability with plot $\mathrm{pH}(\mathrm{KCl})$ means ranging from 2.8 (at $1500 \mathrm{~m}$ ) to 6.2 (at $1000 \mathrm{~m}$ ), while the $\mathrm{pH}(\mathrm{KCl})$ of the mineral soil was much more uniform among the plots (3.9-5.3). The large majority of plots were characterized by moderate to high soil acidities with $\mathrm{pH}(\mathrm{KCl})<5$. The $\mathrm{pH}(\mathrm{KCl})$ of the organic layers decreased significantly with elevation $\left(r^{2}=0.06, p=0.02\right)$, while that of the mineral soil increased $\left(r^{2}=0.36, p<0.001\right)$. Organic layer depth was positively correlated with the $\mathrm{pH}(\mathrm{KCl})$ of the mineral soil $\left(r^{2}=0.34, p<0.001\right)$. 


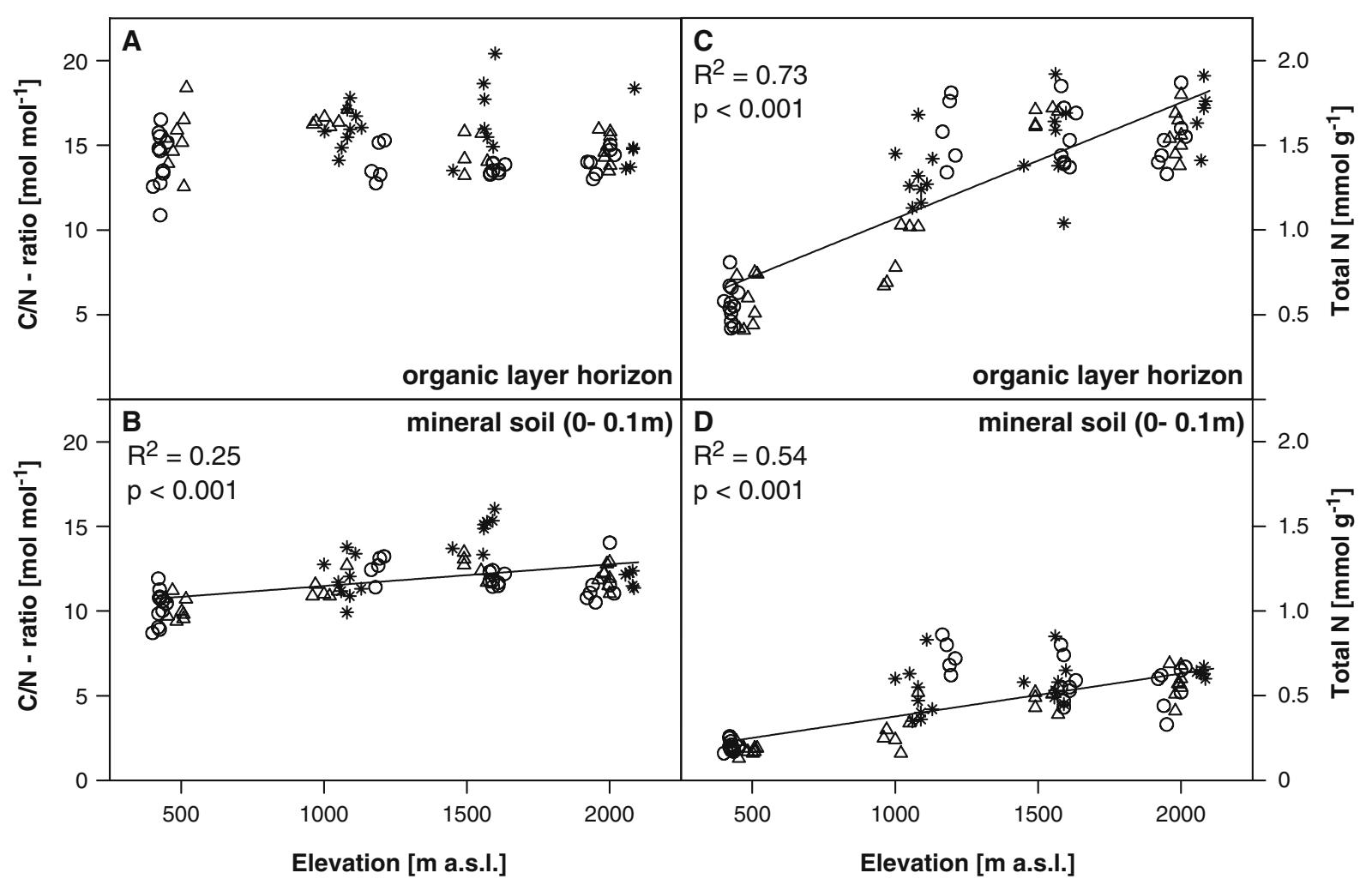

Fig. $3 \mathrm{C} / \mathrm{N}$ ratio and total nitrogen concentration of the soil in the 80 study plots as a function of elevation. a $\mathrm{C} / \mathrm{N}$ ratio of the organic layer and $\mathbf{b}$ of the mineral topsoil $(0-0.1 \mathrm{~m})$, $\mathbf{c}$ total

Availability of $\mathrm{Ca}, \mathrm{K}, \mathrm{Mg}$ and $\mathrm{Al}$

The concentration of salt-exchangeable $\mathrm{K}$ in the organic layer ranged from 2.6 to $48 \mathrm{\mu molg}^{-1}$ (plot means). Despite a large within- and between-site variability, the $\mathrm{K}_{\mathrm{ex}}$ concentration in the organic layer was positively correlated with elevation $\left(r^{2}=0.38\right.$, $p<0.001)$. In contrast, the $\mathrm{K}_{\mathrm{ex}}$ concentration in the mineral soil did not depend on elevation, and was about 10 times lower than that in the organic layer. Similarly variable were the exchangeable $\mathrm{Mg}$ concentrations of the organic layer (plot means from 10.9 to $\left.135 \mu \mathrm{molg}^{-1}\right)$ and of the mineral soil $(0.8$ to $\left.18.5 \mu \mathrm{molg}^{-1}\right)$. The $\mathrm{Mg}_{\mathrm{ex}}$ concentration of the organic layer was positively correlated with elevation and also with the $\mathrm{pH}(\mathrm{KCl})\left(r^{2}=0.12, p<0.001\right.$; $r^{2}=0.15, p<0.001$, respectively), while the $\mathrm{Mg}_{\mathrm{ex}}$ concentration of the mineral soil showed no correlation neither with elevation nor with $\mathrm{pH}(\mathrm{KCl})$. The plot means of the salt-exchangeable $\mathrm{Ca}$ concentration in the organic layer varied between 45 and nitrogen concentration of the organic layer and $\mathbf{d}$ of the mineral soil. For symbols of the different study sites see Fig. 2

$687 \mu \mathrm{molg}^{-1}$ and those of $\mathrm{Ca}_{\mathrm{ex}}$ of the mineral soil between 4.2 and $238 \mu \mathrm{molg}^{-1} \cdot \mathrm{Ca}_{\mathrm{ex}}$ of the organic layer showed a significant, but not very tight, correlation with elevation $\left(r^{2}=0.04, p=0.03\right)$, while $\mathrm{Ca}_{\mathrm{ex}}$ of the mineral soil was independent from elevation. Both variables were positively correlated with $\mathrm{pH}(\mathrm{KCl})\left(r^{2}=0.43, p<0.001 ; r^{2}=0.25\right.$, $p<0.001$, respectively).

The exchangeable aluminium concentration in the organic layers was below the detection limit in various plots at 500, 1000 and $2000 \mathrm{~m}$ elevation, but reached plot means as high as $286 \mu^{m o l g}{ }^{-1}$ in other stands. In the organic layer, the $\mathrm{Al}_{\mathrm{ex}}$ means were positively correlated with elevation $\left(r^{2}=0.08, p=0.005\right)$. The $\mathrm{Al}_{\mathrm{ex}}$ concentration of the mineral topsoil ranged from $4.4 \mu \mathrm{molg}^{-1}$ (lowest plot mean) to $179 \mu_{\mathrm{molg}}^{-1}$ and was not correlated with elevation. Unlike $\mathrm{K}_{\mathrm{ex}}$ and $\mathrm{Mg}_{\mathrm{ex}}$ of the mineral soil, which were positively correlated with $\mathrm{Ca}_{\mathrm{ex}}\left(r^{2}=0.08, p=0.005 ; r^{2}=0.35, p<0.001\right.$, respectively), $\mathrm{Al}_{\mathrm{ex}}$ was negatively correlated with $\mathrm{Ca}_{\mathrm{ex}}$ of the mineral soil $\left(r^{2}=0.05, p=0.02\right)$. 


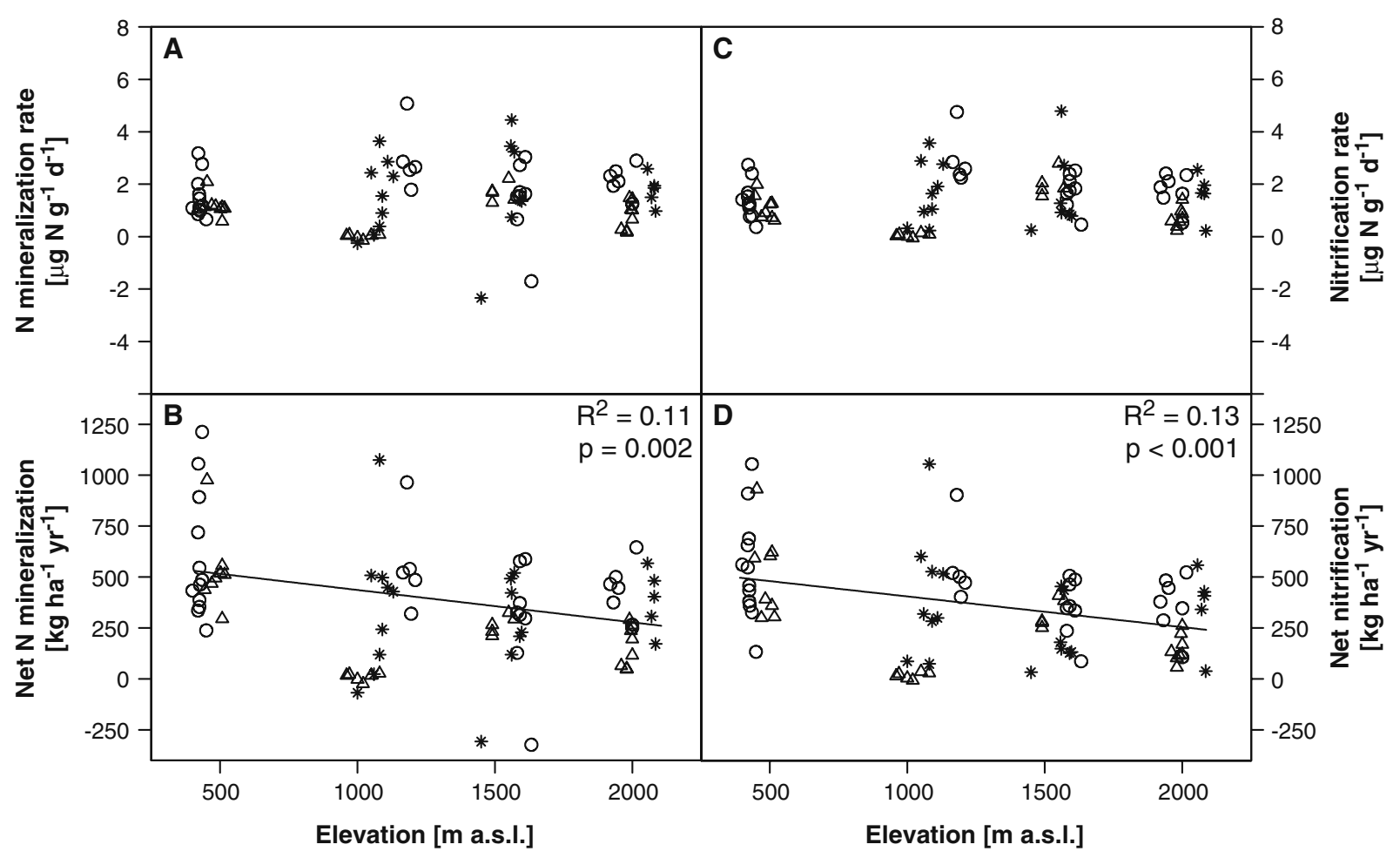

Fig. 4 Net mineralization of $\mathrm{N}$ in the 80 plots as a function of elevation either expressed per soil mass and day (a mineralization rate), or extrapolated to a full year and related to ground area (b net $\mathrm{N}$ mineralization). Net release of nitrate either expressed per soil mass and day (c nitrification rate), or

Phosphorus availability

Plant-available phosphorus $\left(\mathrm{P}_{\mathrm{a}}\right)$, estimated by the resin-bag exchange method, showed a very large variability among the plots at all four elevation levels. In general, the $\mathrm{P}_{\mathrm{a}}$ concentrations were much higher (about 6 times) in the organic layer than in the upper mineral soil ( $0-0.1 \mathrm{~m}$, Fig. $2 \mathrm{a}$ and $\mathrm{b})$. In the former, $\mathrm{P}_{\mathrm{a}}$ plot means varied between 0.03 and $23.3 \mu \mathrm{molP}_{\mathrm{a}}$ $\mathrm{g}^{-1}$, in the latter, $\mathrm{P}_{\mathrm{a}}$ minima were below the detection limit of our method, while maxima reached $4.86 \mu \mathrm{molg}^{-1}$. Despite this high spatial variability, $\mathrm{P}_{\mathrm{a}}$ in the organic layer and in the mineral soil tended to increase with elevation more than tenfold, with the difference between the elevation levels being significant for the 1500 to $2000 \mathrm{~m}$ transition (Fig. 2a and b). This altitudinal trend persisted even if certain very high $\mathrm{P}_{\mathrm{a}}$ values of the Yanayacu plots at $2000 \mathrm{~m}$ were excluded as outliers from the analysis. Both the $\mathrm{P}_{\mathrm{a}}$ concentrations of the organic layer and of the mineral soil showed a positive correlation with $\mathrm{pH}(\mathrm{KCl})$ extrapolated to a full year and related to ground area (d net nitrification). For symbols of the different study sites see Fig. 2. The topsoil $(0.1 \mathrm{~m})$ consists of the organic layer and part of the mineral soil

( $r^{2}=0.06, p=0.01 ; r^{2}=0.07, p=0.009$, respectively). The concentration of total $\mathrm{P}\left(\mathrm{P}_{\mathrm{t}}\right)$ was only measured in the organic layer and ranged from 15.7 to $209 \mu \mathrm{mol}$ $\mathrm{g}^{-1}$ revealing a weak negative correlation with elevation (Fig. 2c) while not being related to $\mathrm{pH}$ $(\mathrm{KCl})$. The between-plot variability of $\mathrm{P}_{\mathrm{t}}$ was high at $500 \mathrm{~m}$ (13fold difference between maximum and minimum) but declined with increasing elevation (3fold difference at $2000 \mathrm{~m}$ ).

$\mathrm{N}$ concentrations and $\mathrm{N}$ mineralization rate

The nitrogen concentration in the organic material of the $\mathrm{L}, \mathrm{F}, \mathrm{H}$ layers increased from $0.58 \mathrm{mmolg}^{-1}$ at $500 \mathrm{~m}$ to $1.59 \mathrm{mmolg}^{-1}$ at 2000 ma.s.l. with lowest and highest plot means of 0.4 and $1.9 \mathrm{mmolg}^{-1}$ (Fig. 3c). In contrast, no elevational trend in the organic layer $\mathrm{C} / \mathrm{N}$ ratio was detected (14.7-15.7 mol $\mathrm{mol}^{-1}$ as means of the elevation levels, Fig. 3a). The total nitrogen $\left(\mathrm{N}_{\mathrm{t}}\right)$ concentration of the mineral topsoil increased from 0.20 to $0.52 \mathrm{mmolg}^{-1}$ from 500 to 
Table 1 Percental contribution of four different sources of variation to the total variation $(=100 \%)$ of various soil chemical parameters in the 80-plot sample according to a variance components analysis (mixed model, all effects random). The relative importance of the components of variation was estimated with the routine REML, calculated with the statistical program R (version 2.8.1, Crawley 2007). The data set consisted of 4 elevation levels $(500,1000,1500$ and $2000 \mathrm{~m}$ ), 3 study sites per elevation (500 m: 2), 5-12 plots per study site, and 4 sampling locations $\left(\mathrm{N}_{\mathrm{NM}}\right.$ and $\left.\mathrm{N}_{\mathrm{NI}}: 8\right)$ per plot.

\begin{tabular}{|c|c|c|c|c|}
\hline Parameter & $\begin{array}{l}\text { Within-plot } \\
\text { variation }\end{array}$ & $\begin{array}{l}\text { Within-site variation } \\
\text { (between-plot variation) }\end{array}$ & $\begin{array}{l}\text { Between-site variation } \\
\text { (at a given elevation) }\end{array}$ & $\begin{array}{l}\text { Variation due to } \\
\text { elevation differences }\end{array}$ \\
\hline Depth of organic layer & 19,9 & 16,5 & 5,7 & 57,9 \\
\hline \multicolumn{5}{|l|}{ Organic layer } \\
\hline $\mathrm{pH}_{\mathrm{KCl}}$ & 30,3 & 28,4 & 16,8 & 24,5 \\
\hline $\mathrm{N}_{\mathrm{t}}$ & 16,3 & 5,4 & 11,1 & 67,2 \\
\hline $\mathrm{C} / \mathrm{N}$-ratio & 48,5 & 31,7 & 19,8 & 0,0 \\
\hline $\mathrm{K}_{\mathrm{ex}}$ & 32,1 & 32,5 & 2,1 & 33,3 \\
\hline $\mathrm{Mg}_{\mathrm{ex}}$ & 48,6 & 21,5 & 20,8 & 9,1 \\
\hline $\mathrm{Ca}_{\mathrm{ex}}$ & 34,1 & 28,8 & 28,9 & 8,2 \\
\hline $\mathrm{Al}_{\mathrm{ex}}$ & 56,9 & 15,1 & 28,0 & 0,0 \\
\hline $\mathrm{P}_{\mathrm{a}}$ & 20,1 & 27,1 & 26,7 & 26,1 \\
\hline $\mathrm{P}_{\mathrm{t}}$ & 37,1 & 43,9 & 19,0 & 0,0 \\
\hline \multicolumn{5}{|l|}{ Mineral soil $(0-0.1 \mathrm{~m})$} \\
\hline $\mathrm{pH}_{\mathrm{KCl}}$ & 40,6 & 19,2 & 11,7 & 28,5 \\
\hline $\mathrm{N}_{\mathrm{t}}$ & 23,0 & 11,9 & 21,3 & 43,8 \\
\hline $\mathrm{C} / \mathrm{N}$-ratio & 24,1 & 18,4 & 22,5 & 35,0 \\
\hline $\mathrm{K}_{\mathrm{ex}}$ & 72,4 & 13,6 & 5,8 & 8,2 \\
\hline $\mathrm{Mg}_{\mathrm{ex}}$ & 60,5 & 28,5 & 4,6 & 6,4 \\
\hline $\mathrm{Ca}_{\mathrm{ex}}$ & 42,5 & 43,4 & 14,1 & 0,0 \\
\hline $\mathrm{Al}_{\text {ex. }}$ & 72,3 & 12,7 & 15,0 & 0,0 \\
\hline $\mathrm{P}_{\mathrm{a}}$ & 33,9 & 28,3 & 23,7 & 14,1 \\
\hline \multicolumn{5}{|c|}{ Topsoil horizon (organic layer and part of uppermost mineral soil) } \\
\hline $\mathrm{N}$ mineralization rate $\left(\mathrm{N}_{\mathrm{NM}}\right)$ & 65,4 & 24,0 & 5,2 & 5,4 \\
\hline $\mathrm{N}$ nitrification rate $\left(\mathrm{N}_{\mathrm{NI}}\right)$ & 54,2 & 30,5 & 10,6 & 4,7 \\
\hline
\end{tabular}

$1000 \mathrm{~m}$ elevation but remained constant higher upslope (minima and maxima along the transect: 0.1 and $0.9 \mathrm{mmolg}^{-1}$, Fig. 3d). With elevation level means of 10.2 to $13.1 \mathrm{molmol}^{-1}$, the $\mathrm{C} / \mathrm{N}$ ratio of the mineral soil was lower than that of the organic layer, and it significantly increased from 500 to $1500 \mathrm{~m}$, but dropped again toward the 2000-m level (Fig. 3b).

$\mathrm{N}_{\mathrm{t}}$ and $\mathrm{C} / \mathrm{N}$ ratio of the mineral soil were positively correlated with $\mathrm{pH}(\mathrm{KCl})\left(r^{2}=0.23, p<0.001 ; r^{2}=0.05\right.$, $p=0.03$, respectively), while $\mathrm{N}_{\mathrm{t}}$ of the organic layer was negatively related to $\mathrm{pH}(\mathrm{KCl})\left(r^{2}=0.10, p=0.002\right)$.

The experiments with in situ-incubation of topsoil samples revealed a negative net ammonium release rate in 40 of the 80 plots, i.e. an immobilisation of $\mathrm{NH}_{4}^{+}$at a maximum rate of $2.6 \mu \mathrm{gN} \mathrm{g}^{-1} \mathrm{~d}^{-1}$. Highest $\mathrm{NH}_{4}^{+}$ release rates reached $2.2 \mu \mathrm{gN} \mathrm{g}^{-1} \mathrm{~d}^{-1}$ at the plot level. Rates of $\mathrm{NO}_{3}^{-}$release (net nitrification rate) varied between $0.01 \mu \mathrm{gg}^{-1} \mathrm{~d}^{-1}$ and $4.79 \mu \mathrm{gg}^{-1} \mathrm{~d}^{-1}$ as plotlevel means, while $\mathrm{N}$ mineralization rate (i.e. the sum of net $\mathrm{NH}_{4}{ }^{+}$and $\mathrm{NO}_{3}{ }^{-}$release) ranged between large negative values (up to $-2.34 \mu \mathrm{gN} \mathrm{g}^{-1} \mathrm{~d}^{-1}$ ) at plots with intensive ammonium immobilisation to $5.08 \mu \mathrm{gN} \mathrm{g}^{-1}$ $\mathrm{d}^{-1}$ in soils with rapid ammonification and subsequent nitrification. The relative proportion of $\mathrm{NO}_{3}{ }^{-}$release of the total of mineral $\mathrm{N}$ released exceeded $80 \%$ in all plots and typically ranged between 95 and $100 \%$.

The dry mass-based net release rate of mineral $\mathrm{N}$ in the uppermost $10 \mathrm{~cm}$ of the soil was independent of elevation (Fig. 4a and c). Only when $\mathrm{N}$ release is expressed per soil volume and ground area (termed net $\mathrm{N}$ mineralization and net nitrification; unit: $\mathrm{kgNha}^{-1} \mathrm{~d}^{-1}$ ), net mineralization and nitrification rate decreased with altitude (Fig. $4 \mathrm{~b}$ and d). This altitude effect was caused by a significant increase in organic layer depth, 
Table 2 Means $( \pm 1 \mathrm{SE}$ $n=20)$ of various soil properties of the organic layer and the mineral topsoil $(0-0.1 \mathrm{~m})$ at 500,1000 1500 and $2000 \mathrm{~m}$ elevation in the Sumaco Biosphere Reserve transect. $\mathrm{K}_{\mathrm{ex}}, \mathrm{Mg}_{\mathrm{ex}}$, $\mathrm{Ca}_{\text {ex }}, \mathrm{Al}_{\text {ex }}-\mathrm{BaCl}_{2}$-exchangeable concentrations of $\mathrm{K}, \mathrm{Mg}, \mathrm{Ca}$ and $\mathrm{Al}$, $\mathrm{P}_{\mathrm{a}}$ - available $\mathrm{P}$ fraction according to the resin-bag method, $\mathrm{P}_{\mathrm{t}}$ - total P. Mean $\mathrm{Ca} / \mathrm{Al}$ ratio was calculated by averaging over the 20 plot means of $\mathrm{Ca} / \mathrm{Al}$ ratio per elevation level. Different small letters indicate significant differences between the elevations

\begin{tabular}{|c|c|c|c|c|}
\hline Parameter & 500 & 1000 & 1500 & 2000 \\
\hline \multicolumn{5}{|l|}{ Organic layer } \\
\hline Depth of organic layers [m] & $0.158 \pm 0.021^{\mathrm{a}}$ & $0.239 \pm 0.031^{\mathrm{a}}$ & $0.634 \pm 0.047^{\mathrm{b}}$ & $0.534 \pm 0.032^{b}$ \\
\hline Soil bulk density $\left[\mathrm{Mgm}^{-3}\right]$ & $1.13 \pm 0.04^{\mathrm{a}}$ & $0.63 \pm .003^{\mathrm{b}}$ & $0.47 \pm 0.02^{\mathrm{b}}$ & $0.57 \pm .01^{\mathrm{b}}$ \\
\hline $\mathrm{pH}_{\mathrm{KCl}}$ & $4.66 \pm 0.56^{\mathrm{a}}$ & $5,28 \pm 0.65^{\mathrm{a}}$ & $3.86 \pm 0.46^{\mathrm{b}}$ & $4.69 \pm 0.57^{\mathrm{a}}$ \\
\hline $\mathrm{K}_{\mathrm{ex}}\left[\mu \mathrm{molg}^{-1}\right]$ & $6.69 \pm 0.57^{\mathrm{a}}$ & $12.95 \pm 0.70^{\mathrm{b}}$ & $13.05 \pm 1.28^{\mathrm{b}}$ & $20.77 \pm 2.31^{\mathrm{c}}$ \\
\hline $\mathrm{Mg}_{\mathrm{ex}}\left[\mu \mathrm{molg}^{-1}\right]$ & $32.47 \pm 3.28^{\mathrm{a}}$ & $47.39 \pm 2.52^{\mathrm{ab}}$ & $36.06 \pm 3.26^{\mathrm{a}}$ & $54.05 \pm 5.39^{\mathrm{b}}$ \\
\hline $\mathrm{Ca}_{\mathrm{ex}}\left[\mu \mathrm{molg}^{-1}\right]$ & $136.07 \pm 12.18^{\mathrm{a}}$ & $275.38 \pm 39.22^{\mathrm{b}}$ & $146.13 \pm 20.78^{\mathrm{a}}$ & $250.15 \pm 22.18^{\mathrm{b}}$ \\
\hline $\mathrm{Al}_{\mathrm{ex}}\left[\mu \mathrm{molg}^{-1}\right]$ & $18.91 \pm 3.34^{\mathrm{a}}$ & $62.59 \pm 17.78^{\mathrm{ab}}$ & $73.64 \pm 9.06^{\mathrm{b}}$ & $50.76 \pm 8.26^{\mathrm{ab}}$ \\
\hline $\mathrm{Ca}_{\mathrm{ex}} / \mathrm{Al}_{\mathrm{ex}}$ ratio $\left[\mathrm{molmol}^{-1}\right]$ & $9.68 \pm 1.93^{\mathrm{ab}}$ & $17.10 \pm 8.72^{\mathrm{b}}$ & $3.76 \pm 1.22^{\mathrm{a}}$ & $6.00 \pm 1.24^{\mathrm{a}}$ \\
\hline \multicolumn{5}{|l|}{ Mineral soil $(0-0.1 \mathrm{~m})$} \\
\hline $\mathrm{pH}_{(\mathrm{KCl})}$ & $4.08 \pm 0.42^{\mathrm{a}}$ & $4.47 \pm 0.54^{b}$ & $4.44 \pm 0.46^{\mathrm{bc}}$ & $4.51 \pm 0.47^{\mathrm{c}}$ \\
\hline $\mathrm{K}_{\mathrm{ex}}\left[\mu \mathrm{molg}{ }^{-1}\right]$ & $1.72 \pm 0.17^{\mathrm{a}}$ & $2.54 \pm 0.16^{\mathrm{b}}$ & $1.64 \pm 0.15^{\mathrm{a}}$ & $1.86 \pm 0.20^{\mathrm{a}}$ \\
\hline $\mathrm{Mg}_{\mathrm{ex}}\left[\mu \mathrm{molg}{ }^{-1}\right]$ & $5.70 \pm 0.53^{\mathrm{ab}}$ & $7.56 \pm 0.85^{\mathrm{a}}$ & $4.51 \pm 0.56^{\mathrm{b}}$ & $4.73 \pm 0.70^{\mathrm{b}}$ \\
\hline $\mathrm{Ca}_{\mathrm{ex}}\left[\mu \mathrm{molg}^{-1}\right]$ & $14.22 \pm 2.08^{\mathrm{a}}$ & $41.28 \pm 11.97^{\mathrm{a}}$ & $21.96 \pm 4.10^{\mathrm{a}}$ & $30.35 \pm 7.45^{\mathrm{a}}$ \\
\hline $\mathrm{Al}_{\mathrm{ex}}\left[\mu \mathrm{molg}^{-1}\right]$ & $44.85 \pm 5.29^{\mathrm{a}}$ & $57.20 \pm 7.76^{\mathrm{a}}$ & $44.33 \pm 3.55^{\mathrm{a}}$ & $40.48 \pm 5.70^{\mathrm{a}}$ \\
\hline $\mathrm{Ca}_{\mathrm{ex}} / \mathrm{Al}_{\mathrm{ex}}$ ratio $\left[\mathrm{molmol}^{-1}\right]$ & $0.63 \pm 0.24^{\mathrm{a}}$ & $2.23 \pm 1.32^{\mathrm{a}}$ & $0.54 \pm 0.12^{\mathrm{a}}$ & $1.23 \pm 0.32^{\mathrm{a}}$ \\
\hline
\end{tabular}

associated with a decrease in the bulk density of the topsoil, in upslope direction. Both net mineralization and net nitrification were positively correlated with soil bulk density $\left(r^{2}=0.19, p<0.001\right.$ and $r^{2}=0.18, p<0.01$, respectively) and also with soil moisture $\left(r^{2}=0.16\right.$, $p<0.001$ and $r^{2}=0.14, p<0.01$, respectively).

In an attempt to compare the availabilities of $\mathrm{N}$ and $\mathrm{P}$ along the slope, we calculated different nutrient ratios (Fig. 5a-d). While the $\mathrm{N}_{\mathrm{t}} / \mathrm{P}_{\mathrm{t}}$-ratio of the organic layer increased with elevation $\left(r^{2}=0.25, p<0.001\right)$, the $\mathrm{N}_{\mathrm{t}} /$ $\mathrm{P}_{\mathrm{a}}$-ratio (resin bag method) of both the organic layer and the mineral topsoil decreased exponentially with altitude $\left(r^{2}=0.12, p=0.001\right.$ and $r^{2}=0.06, p=0.01$, respectively). By relating $\mathrm{N}$ mineralization or nitrification rate $\left(\mathrm{N}_{\mathrm{NM}}\right.$ or $\left.\mathrm{N}_{\mathrm{NI}}\right)$ to available phosphorus $\mathrm{P}_{\mathrm{a}}$, we obtained $\mathrm{N}_{\mathrm{NM}} / \mathrm{P}_{\mathrm{a}}$ and $\mathrm{N}_{\mathrm{NI}} / \mathrm{P}_{\mathrm{a}}$ ratios which showed similarly exponential decreases with altitude $\left(r^{2}=0.24\right.$, $\left.p=0.001 ; r^{2}=0.30, p<0.001\right)$ as did the $\mathrm{N}_{\mathrm{t}} / \mathrm{P}_{\mathrm{a}}$ ratios.

\section{Discussion}

Elevational change in $\mathrm{N}$ availability

Mean rates of $\mathrm{N}$ net mineralization as obtained from 8-d in situ-incubations were close to values reported from other tropical forests on moderately fertile soils
(1-3 $\mu \mathrm{gN} \mathrm{g}^{-1} \mathrm{~d}^{-1}$ ), while lower mineralization rates were observed in forests on oxisols, ultisols or other less fertile substrates, and also in some montane forests $\left(0.1-1 \mu \mathrm{gN} \mathrm{g}^{-1} \mathrm{~d}^{-1}\right.$, Lamb 1980; Robertson 1984; Chandler 1985; Vitousek and Denslow 1986; Vitousek and Sanford 1986; Matson et al. 1987; Marss et al. 1988; Montagnini and Buschbauer 1989). That the mineralization rates in East Ecuador were relatively high at montane elevation may be explained by the rather low $\mathrm{C} / \mathrm{N}$ ratios along this transect.

To test the hypothesis that nitrogen availability decreases with elevation in tropical mountain forests, we investigated different variables characterizing $\mathrm{N}$ availability, (i) $\mathrm{N}$ net mineralization (and nitrification) rate per soil dry mass, i.e. the specific activity of mineralizing soil bacteria and fungi, (ii) $\mathrm{N}$ net mineralization rate per soil volume and ground area as a measure of mineral $\mathrm{N}$ supply to plant roots, and (iii) soil $\mathrm{C} / \mathrm{N}$ ratio as an indicator of the decomposability of soil organic matter. Soil mass-related $\mathrm{N}$ net mineralization and nitrification rate remained invariant between 500 and $2000 \mathrm{~m}$ along the transect, indicating that a decrease in mean temperature by more than $8^{\circ} \mathrm{C}$ had no effect on the mineralizing activity of the soil biota. This contrasts with frequent reports about a slowing down of $\mathrm{N}$ mineralization in cooler environments 


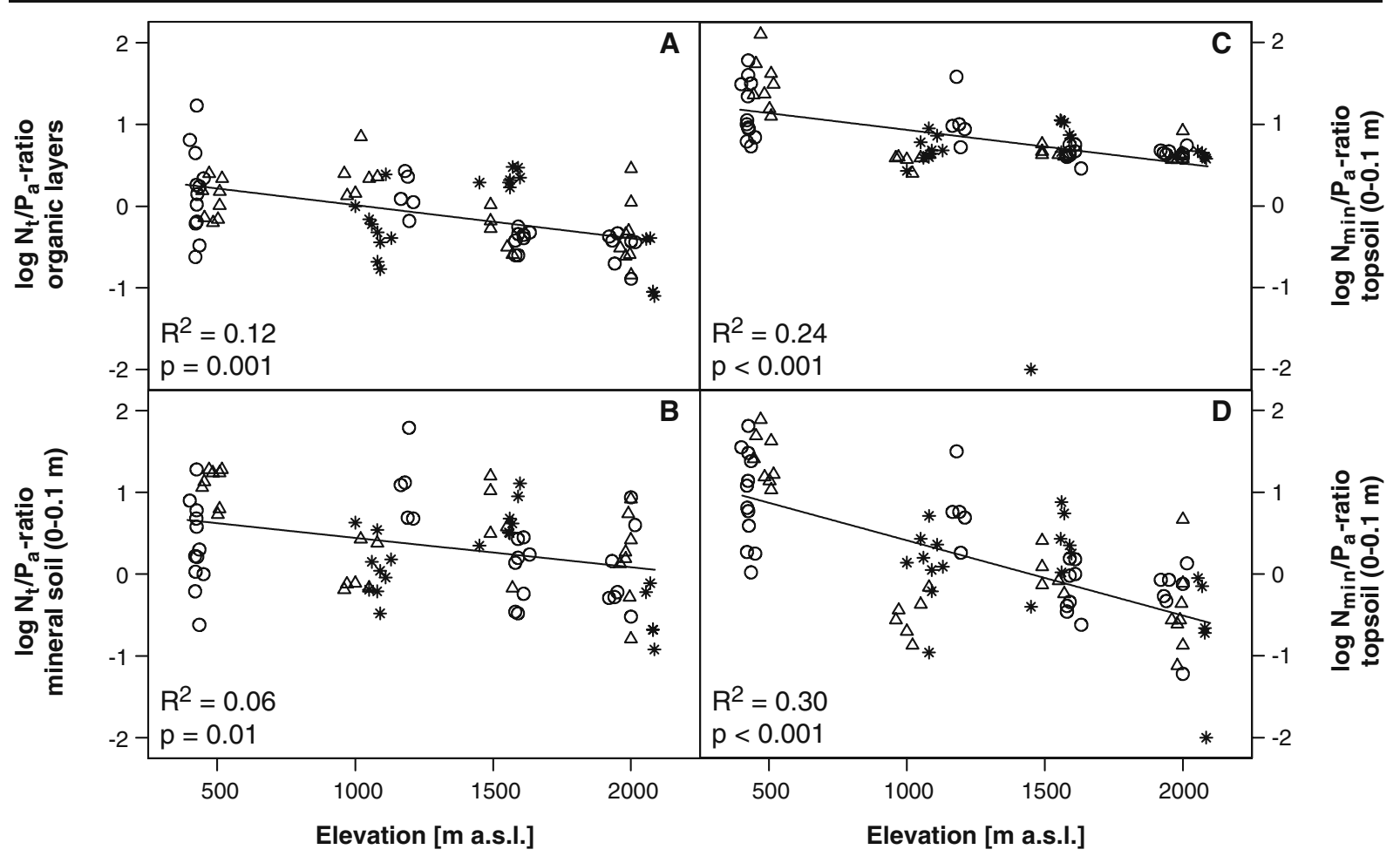

Fig. 5 Ratio (log-transformed) of total nitrogen to plantavailable phosphorus of the organic layer (a) or the mineral soil $(0-0.1 \mathrm{~m})(\mathbf{b})$, and ratio (log-transformed) of $\mathrm{N}$ mineralization rate $\left(\mathrm{N}_{\mathrm{NM}}\right.$, c) or nitrification rate $\left(\mathrm{N}_{\mathrm{NI}}\right.$, d) to plantavailable phosphorus of the topsoil (mixture of organic layer

(e.g. Meentemeyer 1977; Sveinbjörnsson et al. 1995; Timoney 1995; Sveinbjörnsson 2000). However, our observation of a negligible temperature effect on net mineralization is supported by the experiments of Marss et al. (1988) who suggested that low temperature is unlikely a major constraint of soil $\mathrm{N}$ transformation in tropical mountain forests because soils from higher altitudes, when incubated in the lowlands at $100 \mathrm{~m}$ elevation, did not reveal higher $\mathrm{N}$ mineralization or nitrification rates. This may indicate that the microbial communities of the different elevation levels are well adapted in their metabolic rate to the local thermal regime. If so, other factors such as elevated foliar phenol contents or the more frequent occurrence of water-saturated soils and hypoxia might limit $\mathrm{N}$ mineralization at high altitudes.

Only minor changes in substrate quality may be one reason for the observed constancy of mineralization rate with elevation in our transect. In the literature, there are contrasting reports on altitudinal and mineral soil horizon, $0-0.1 \mathrm{~m})(n=80)$. The $\mathrm{r}^{2}$ and $\mathrm{p}$ values refer to the original non-linear relationships before logtransformation. To avoid division by zero, 0.01 was added to all $\mathrm{P}_{\mathrm{a}}$ values in the data of Fig. $5 \mathrm{~b}$

change in soil organic matter $\mathrm{C} / \mathrm{N}$ ratio in tropical mountains. Similar to our data, Arnold et al. (2008) and Proctor et al. (1988) reported more or less constant $\mathrm{C} / \mathrm{N}$ ratios in NW Ecuadorian and Malaysian mountain transects, while Moser et al. (2008) found a pronounced increase of topsoil $\mathrm{C} / \mathrm{N}$ ratio with elevation in a south Ecuadorian transect. This points to an important influence of bedrock type on soil $\mathrm{N}$ content and its altitudinal variation. In Central and Northern Ecuador, many summits are volcanoes, that develop Andosols at higher elevations with relatively high nitrogen concentrations when aged, while they are infrequent in $\mathrm{S}$ Ecuador.

$\mathrm{N}$ availability to plant uptake is best characterized by $\mathrm{N}$ mineralization rate per soil volume and stand area (per $\mathrm{m}^{2}$ and $0-0.1 \mathrm{~m}$ depth). Other than massrelated mineralization rate, $\mathrm{N}$ mineralization and nitrification per stand area decreased by about $40 \%$ between 500 and $2000 \mathrm{~m}$, supporting our first hypothesis. This is mostly a consequence of the fact that the humus content of the topsoil increased toward 
higher elevations in this transect, thereby reducing soil bulk density and lowering volume-related mineral $\mathrm{N}$ release rates.

Another factor that could influence $\mathrm{N}$ availability to plants in tropical montane forests is the depth of the organic layers which typically increases with elevation (in our transect three- to fourfold). Due to higher $\mathrm{N}$ concentrations, organic material on top of the soil generally has higher mass-related $\mathrm{N}$ mineralization rates than the mineral soil underneath. Organic layers at high elevation thus may support relatively high $\mathrm{N}$ release rates on a ground area basis, which could partly compensate for reductions in $\mathrm{N}$ mineralization rate per soil mass or soil volume. Because we measured $\mathrm{N}$ mineralization only in the uppermost $0.1 \mathrm{~m}$ of the soil profile, we have no data on the activity of lower soil horizons and thus cannot conclude on the potential role of an increasing organic layer depth for $\mathrm{N}$ availability.

\section{Elevational change in $\mathrm{P}$ availability}

The availability of phosphorus to plants depends on a variety of geochemical and biological factors, several of them being difficult to measure under field conditions. Furthermore, a fully agreed analytical procedure to quantify plant-available $\mathrm{P}$ in forest soils does not yet exist. We used two approaches to obtain estimates of plant-available $\mathrm{P}$ in the topsoil horizons: first, total $\mathrm{P}$ in the organic layers was determined for quantifying the pool of $\mathrm{P}$ bound in fresh litter and humus material on top of the mineral soil. Part of this pool, especially that bound in the easily-degradable humus fraction, may be readily available as inorganic $\mathrm{P}$ after fungal or microbial mineralization, while $\mathrm{P}$ bound in recalcitrant organic molecules may resist biological degradation for much longer time (Walker and Syers 1976). A second approach used resin bags as anion exchangers to quantify the amount of inorganic $\mathrm{P}$ in organic layers and mineral topsoil by applying a standardized procedure. Most likely, this technique measures soil solution $\mathrm{P}$ and part of the non-specifically adsorbed $\mathrm{P}$, thereby approaching the plant-available fraction, while tightly bound P (precipitated and occluded fractions) will not be removed by the anion exchangers (Irion 1978; Uehara and Gillman 1981). Clearly, additional P fractions may be available to plants as well that are not measured by this technique, notably organic and inorganic $\mathrm{P}$ mobilized by external phosphatases and other rhizosphere processes. Our data show a signifi- cant decrease in the total-P concentration of the organic layers from 500 to $2000 \mathrm{~m}$ elevation, and consequently a large increase in the organic matter $C / P_{t}$ ratio (from $39 \mathrm{molmol}^{-1}$ at $500 \mathrm{~m}$ to $>1500 \mathrm{molmol}^{-1}$ at $2000 \mathrm{~m}$, data not shown). Due to the substantial increase in organic layer thickness (and mass), the pool of organic $\mathrm{P}$ nevertheless increased with elevation in our transect. In both investigated horizons, the plant-available (resin-bag exchangeable) $\mathrm{P}$ concentration $\left(\mathrm{P}_{\mathrm{a}}\right)$ increased more than 10 fold from 500 to $2000 \mathrm{~m}$ elevation, which is the largest change with elevation detected for any of the soil chemical parameters investigated in this study. An important finding is that $\mathrm{P}_{\mathrm{a}}$ occurred at about 6-fold higher concentrations in the organic layer than in the mineral topsoil immediately below, indicating large vertical gradients in $\mathrm{P}$ availability in the soil and emphasizing the role of organic matter as the most important $\mathrm{P}$ source in these soils.

Inorganic $\mathrm{P}$ is supplied to the $\mathrm{P}_{\mathrm{a}}$ fraction by desorption processes, in acidic soils mostly from iron and aluminium oxide minerals, $\mathrm{P}$ release through organic matter mineralization, and mineral weathering (Walker and Syers 1976; Irion 1978; Uehara and Gillman 1981; Grierson et al. 1999). Uptake by plants and microbes and, to a lesser extent, leaching with percolating water are processes which deplete the $\mathrm{P}_{\mathrm{a}}$ pool (Olander and Vitousek 2004). Since none of these processes was measured directly, we can only speculate about the causes of the remarkable increase in $\mathrm{P}_{\mathrm{a}}$ concentrations with altitude. $\mathrm{P}_{\mathrm{a}}$ supply through mineral weathering may increase with elevation because erosion tends to rejuvenate the soils of inclined sites in montane elevation, thereby increasing the amount of weatherable P-containing minerals in the upper soil profile, but the effect of weathering on $\mathrm{P}_{\mathrm{a}}$ supply is presumably small due to the rapid turnover of the element and it cannot explain the much smaller $\mathrm{P}_{\mathrm{a}}$ concentration in the mineral soil than in the organic layers. Many tropical lowland soils are dominated by aluminium and iron oxide minerals but are poor in minerals that can release $\mathrm{P}$ through weathering (Sanchez 1976; Högberg 1986; Tiessen et al. 1994). The roughly six-fold higher $P_{a}$ concentration in the organic layer as compared to the mineral soil points to a key role of geochemical adsorption and precipitation processes in reducing the $\mathrm{P}_{\mathrm{a}}$ pool in these soils (Frossard et al. 1995), because P-adsorbing $\mathrm{Fe}$ - and Al-oxides are much more abundant in the 
mineral soil than in the organic layers. Another possible explanation is mineralization of organic substances as a significant $\mathrm{P}$ source filling up the $\mathrm{P}_{\mathrm{a}}$ pool in the organic layers (Grierson et al. 1999). However, P mineralization alone does not explain the observed increase of $\mathrm{P}_{\mathrm{a}}$ with elevation because the mass-specific mineralization rate should decrease with elevation due to much more unfavourable $\mathrm{C} / \mathrm{P}$ ratios, rather than increase, as it was observed for $\mathrm{P}_{\mathrm{a}}$. We speculate that organic anions released through decomposition in the organic layer may play an important role in reducing the adsorption of $\mathrm{P}$ to Aland Fe-oxides. Production of organic anions (such as citric acid) by plant roots or fungi could further reduce P sorption (Hue 1991; Gerke and Meyer 1995). An upslope decrease in the intensity of $P$ immobilization through microbial uptake (see e.g. Olander and Vitousek 2004; McGroddy et al. 2004) is also unlikely because the microbes should be shorter in $\mathrm{P}$ at higher elevations due to the unfavourable organic matter $\mathrm{C} / \mathrm{P}$ ratio. Thus, the most likely explanation is a key role of plant $\mathrm{P}$ demand for the actual $\mathrm{P}_{\mathrm{a}}$ concentration with demand being high at lower elevation and decreasing upslope due to decreasing forest productivity with elevation (Moser et al. submitted).

\section{Elevational change in $\mathrm{N}$ versus $\mathrm{P}$ limitation}

With a decrease by $40 \%$ in $\mathrm{N}$ mineralization rate per stand area from 500 to $2000 \mathrm{~m}$, we found some evidence in support of the hypothesis that $\mathrm{N}$ availability tends to decrease with elevation (see also Grubb 1977; Edwards and Grubb 1977; Edwards 1982), even though the organic matter $\mathrm{C} / \mathrm{N}$ ratio remained favourable at all elevations and total $\mathrm{N}$ concentration of the topsoil increased in upslope direction. However, with mean daily $\mathrm{N}$ mineralization rates in the range of $1.5-1.6 \mu \mathrm{gN} \mathrm{g}^{-1} \mathrm{~d}^{-1}$, the montane forests (1500-2000 m) of NE Ecuador were supplied with similar mineral $\mathrm{N}$ amounts as have been found in moderately fertile tropical lowland forest soils. This indicates that $\mathrm{N}$ limitation of tree growth is probably less severe in the Sumaco montane forests than in other tropical montane forests on non-volcanic bedrock with higher soil $\mathrm{C} / \mathrm{N}$ ratios. When relating the availabilities of $\mathrm{N}$ and $\mathrm{P}$ to each other in a quotient of $\mathrm{N}_{\mathrm{NM}}: \mathrm{P}_{\mathrm{a}}$ (or $\mathrm{N}_{\mathrm{NI}}: \mathrm{P}_{\mathrm{a}}$ ), we found an exponential 30 -fold decrease in the $\mathrm{N} / \mathrm{P}$ ratio from
500 to $2000 \mathrm{~m}$ elevation (Fig. 5). This is strong support for a decreasing importance of $\mathrm{P}$ limitation over $\mathrm{N}$ limitation with increasing elevation, irrespective of the overall significance of nutrient limitation of tree growth in these forests. Fertilization experiments at different elevations are needed to test for growth implications of this shift in N/P availability.

Soil acidity and the availability of $\mathrm{Ca}, \mathrm{Mg}$ and $\mathrm{K}$

Our results support our second hypothesis that, with increasing elevation, the nutrient availability to plants is improved by growing nutrient stocks in the organic layers. The pools of salt-exchangeable $\mathrm{Ca}, \mathrm{Mg}$ and $\mathrm{K}$ in the organic layers increased with elevation due to both a large increase in organic layer depth and also higher $\mathrm{Ca}_{\mathrm{ex}}, \mathrm{Mg}_{\mathrm{ex}}$ and $\mathrm{K}_{\mathrm{ex}}$ concentrations at higher elevations in the organic material. In the organic layers, much more $\mathrm{Ca}, \mathrm{K}$ and $\mathrm{Mg}$ was bound to cation exchangers on a mass basis than in the mineral soil which underlines the importance of the organic layers not only for $\mathrm{N}$ and $\mathrm{P}$ supply, but also with respect to the supply of basic (non-hydrolyzing) cations (see also Kaufmann et al. 1998; Wilcke et al. 2002; Wilcke et al. 2008). In contrast, significant altitudinal trends in the abundance of salt-exchangeable cations in the mineral soil did not exist (except for slightly smaller $\mathrm{Mg}_{\mathrm{ex}}$ concentrations at 1500 and $2000 \mathrm{~m}$ ).

\section{Conclusions}

By investigating soil chemical parameters, that may characterize the plant-availability of $\mathrm{N}$ and $\mathrm{P}$ satisfactorily, our study provides evidence for an increasing availability of $\mathrm{P}$ and a decreasing availability of $\mathrm{N}$ with altitude in this transect. Remarkably, the decrease in stand-level $\mathrm{N}$ net mineralization occurred not due to the 8 K-temperature drop along the transect (which apparently was compensated by an effective thermal adaptation of the microbial communities at different elevations), but was mostly a consequence of a reduced soil bulk density with increasing altitude. Whether the increasing depth of the organic layers can fully compensate for this effect, must remain unclear in the absence of $\mathrm{N}_{\mathrm{NM}}$ data for lower soil horizons. A discussion of the relevant processes, that control the pool of available $\mathrm{P}$ in the soil, leads us to the 
assumption that the large elevational increase in $\mathrm{P}_{\mathrm{a}}$ is primarily a consequence of a significant reduction in plant demand with increasing altitude, reflecting the reduction in productivity. The most striking change from lowland to montane elevation in relation to soil chemistry and plant nutrition is the very large decrease in the ratio of available $\mathrm{N}$ to available $\mathrm{P}$. Its potential impact on tree growth, tree species composition and nutrient cycling in tropical forests along altitudinal transects deserves further detailed study. Our study also provides evidence for the increasing importance of the organic layers for the supply of N, P and basic cations to the plants in tropical high-elevation forests. Intact humus layers of considerable depth harbour not only large nutrient pools but also were found to contain hugh amounts of tree fine root biomass in Ecuadorian and Costa Rican high-elevation forests (Leuschner et al. 2007; Moser et al. 2008) which underpins the key role of this soil compartment for the ecology of these fragile ecosystems.

Acknowledgements This research was conducted in the context of the collaborative project Pro Benefit funded by the BMBF (Federal Ministry of Education and Science of Germany). The financial support is gratefully acknowledged. We thank the Ministerio del Ambiente de Ecuador for granting the research permit (001-06 DRFN-P/MA), and especially the PUCE (Pontificia Universidad Católica del Ecuador) and the many private reserves for the continuous support during the field studies in Ecuador. Sincere thanks are given to Dr. Franka Berdel for the identification and further analyses of the soils of our study sites and Edzo Veldkamp for helpful comments on the ms.

Open Access This article is distributed under the terms of the Creative Commons Attribution Noncommercial License which permits any noncommercial use, distribution, and reproduction in any medium, provided the original author(s) and source are credited.

\section{References}

Agbenin JO, van Raij B (2001) Kinetics and energetics of phosphate release from tropical soils determined by mixed ion-exchange resins. Soil Sci Soc Am J 65:1108-1114

Arnold J, Corre MD, Veldkamp E (2008) Cold storage and laboratory incubation of intact soil cores do not reflect insitu nitrogen cycling rates of tropical forest soils. Soil Biol Biochem 40:2480-2483

Baldock JW (1982) Geology of Ecuador-Explanatory Bulletin of the National Geological Map of the Republic of Ecuador. Ministerio de Recursos Naturales y Energéticos, Dirección General de Geología y Minas, Quito, 70
Benner J, Vitousek P, Ostertag R (2010) Nutrient cycling and nutrient limitation in tropical montane cloud forests. In: Bruijnzeel LA, Scatena FN, Hamilton LS (eds) Mountains in the mist: Science for Conserving and Managing tropical montane cloud forests. Cambridge University Press, Cambridge

Bruijnzeel LA, Proctor J (1995) Hydrology and biogeochemistry of tropical montane cloud forests: what do we really know? In: Tropical Montane Cloud Forests. Ecological Studies 110. Springer, New York, pp 38-78

Bruijnzeel LA, Waterloo MJ, Proctor J, Kuiters AT, Kotterink B (1993) Hydrological observations in montane rain forests on Gunung Silam, Sabah, Malaysia, with special reference to the 'Massenerhebung' effect. J Ecol 81:145-167

Bower CA, Wilcox LV (1965) Soluble salts. Methods of soil analysis 2. Chemical and microbiological properties. In: Black CA (ed) Agronomy 9. American Society of Agronomy Inc, Madison, pp 933-951

Bowman RA, Cole CV (1978) An exploratory method for fractionation of organic phosphorus from grassland soils. Soil Sci 25:95-101

Cavelier J, Tanner E, Santamaria J (2000) Effect of water, temperature and fertilizers on soil nitrogen net transformations and tree growth in an elfin cloud forest of Colombia. J Trop Ecol 16:83-99

Chandler G (1985) Mineralization and nitrification in three Malaysian forest soils. Soil Biol Biochem 17:347-353

Cuevas E, Medina E (1986) Nutrient dynamic within Amazonian forest ecosystems: I. nutrient flux in fine litter and efficiency of nutrient utilization. Oecologia 68:466-472

Cuevas E, Medina E (1988) Nutrient dynamics within Amazonian forests. II. Fine root growth, nutrient availability and leaf litter decomposition. Oecologia 76:222-235

Edwards PJ (1982) Studies of mineral cycling in a montane rain forest in New Guinea. V.Rates of cycling in throughfall and litter fall. J Ecol 70:807-827

Edwards PJ, Grubb PJ (1977) Studies of mineral cycling in a montane rain forest in New-Guinea. I. Distribution of organic matter in vegetation and soil. J Ecol 65:943969

Edwards PJ, Grubb PJ (1982) Studies of mineral cycling in a montane rain forest in New-Guinea. II. Soil characteristics and the division of mineral elements between the vegetation and soil. J Ecol 70:649-666

Frossard E, Brossard M, Hedley MJ, Metherell A (1995) Reactions controlling the cycling of $\mathrm{P}$ in soils. In: Tiessen $\mathrm{H}$ (ed) Phosphorus in the Global Environment. Transfers, Cycles and Management. Scope 54. Wiley, Chichester, pp 107-137

Gerke J, Meyer U (1995) Phosphate acquisition by red clover and black mustard on a humic podzol. J Plant Nutr 18:2409-2429

Grierson PF, Comerford NB, Jokela EJ (1999) Phosphorus mineralization and microbial biomass in a Florida spodosol: effects of water potential, temperature and fertilizer application. Biol Fertil Soils 28:244-252

Grieve IC, Proctor J, Cousins SA (1990) Soil variation with altitude on volcan Barva, Costa Rica. Catena 17:525-534

Grubb PJ (1977) Control of forest growth and distribution on wet tropical mountains: with reference to mineral nutrition. Annu Rev Ecol Syst 8:83-107 
Grubb PJ (1995) Rainforest dynamics: the need for new paradigms. In: Edwards DS, Booth WE, Choy SC (eds) Tropical Rainforest Research: Current Issues. Kluwer, Dordrecht, pp 215-233

Harrington RA, Fownes JH, Vitousek PM (2001) Production and resource use efficiencies in $\mathrm{N}$ - and P-limited tropical forests: a comparison of responses to long-term fertilization. Ecosystems 4:646-657

Högberg P (1986) Soil nutrient availability, root symbioses and tree species composition in tropical Africa: a review. J Trop Ecol 2:359-372

Hue NV (1991) Effects of organic acids/anions on P sorption and phytoavailability in soils with different mineralogies. Soil Sci 152:463-471

Iost S, Makeschin F, Abiy M, Haubrich F (2008) Biotic soil activities. In: Beck E (ed) Gradients in a tropical mountain ecosystem in Ecuador. Ecological Studies 198. Springer, Berlin, pp 217-228

Irion G (1978) Soil infertility in the Amazonian rain forest. Naturwissenschafien 65:515-519

IUSS Working Group WRB (2006) World Soil Resources Reports No. 103. FAO, Rome

Jackson ML (1958) Soil Chemical Analysis. Prentice Hall, Englewood Cliffs

Jenny H (1980) Soil Genesis with Ecological Perspectives. Springer, New York

Jordan CF, Herreira R (1981) Tropical rainforests: are nutrients really critical? Am Nat 117:167-180

Kaufmann JB, Cummings DL, Ward DE (1998) Fire in the Brazilian Amazon. 2. Biomass, nutrient pools and losses in cattle pasture. Oecologia 113:415-427

Kitayama K, Aiba S-I, Takyu M, Majalap N, Wagai R (2004) Soil phosphorus fractionation and phosphorus-use efficiency of a Bornean tropical montane rain forest during soil aging with podzolization. Ecosystems 7:259-274

Lamb D (1980) Soil nitrogen mineralisation in a secondary rainforest succession. Oecologia 47:257-263

Leuschner C, Moser G, Bertsch C, Röderstein M, Hertel D (2007) Large altitudinal increase in tree root/shoot ratio in tropical mountain forests of Ecuador. Basic Appl Ecol 8:219-230

Marss RH, Proctor J, Heaney A, Mountford MD (1988) Changes in soil nitrogen-mineralization and nitrification along an altitudinal transect in tropical rain forest in Costa Rica. J Ecol 76:466-482

Matson PA, Vitousek PM, Ewel JJ, Mazzarino MJ, Robertson GP (1987) Nitrogen transformations following tropical forest felling and burning on a volcanic soil. Ecology 68:491-502

McGroddy ME, Silver WL, Cosme de Oliveira R (2004) The effect of phosphorus availability on decomposition dynamics in a seasonal lowland Amazonian forest. Ecosystems 7:172-179

Meentemeyer V (1977) Climatic regulation of decomposition rates of organic matter in terrestrial ecosystems. In: Adrians DC, Brisbin IL (eds) Environmental chemistry and cycling processes. US Dep Energy Symp Series CONF-760429, Washington, pp 779-789

Montagnini F, Buschbauer R (1989) Nitrification rates in two undisturbed tropical rainforests and three slash-and-burn sites of the Venezuelan Amazon. Biotropica 21:9-14
Moser G, Röderstein M, Soethe N, Hertel D, Leuschner C (2008) Altitudinal changes in stand structure and biomass allocation of tropical mountain forests in relation to microclimate and soil chemistry. In: Beck E, Bendix J, Kottke I, Makeschin F, Mosandl R (eds) Gradients in a tropical mountain ecosystem of Ecuador. Ecological Studies 198. Springer, Berlin, pp 229-242

Murphy J, Riley R (1962) A modified single solution for the determination of phosphate in natural waters. Anal Chim Acta 27:31-36

Neill DA, Jørgensen PM (1999) Climates. In: Jørgensen PM, León-Yánez S (eds) Catalogue of the Vascular Plants of Ecuador. Missouri Bot Gard Press, St. Louis, pp 8-13

Neill DA, Palacios WA (1997) Gran Sumaco and upper Napo river region, Ecuador. In: Davis SD, Heywood VH, Herrera_MacBryde O, Villa-Lobos J, Hamilton AC (eds) Centers of plant diversity. A guide and strategy for their conservation, Vol. 3. The Americas. IUCN Publ Unit, Cambr, pp 496-550

Olander LP, Vitousek PM (2004) Biological and geochemical sinks for phosphorus in soil from a wet tropical forest. Ecosystems 7:404-419

Palacios W, Cerón C, Valencia R, Sierra R (1999) Las formaciones naturales de la Amazonía del Ecuador. In: Sierra R (ed) Propuesta preliminar de un sistema de clasificación de vegetación para el Ecuador continental. Proyecto INEFAN/GEF-BIRF y EcoCiencia, Quito, pp 109-119

Proctor J, Lee YF, Langley AM, Munro WRC, Nelson T (1988) Ecological studies on Gunung Silam, a small ultrabasic mountain in Sabah, Malaysia. II. Some forest processes. J Ecol 77:317-331

Robertson GP (1984) Nitrification and nitrogen mineralization in a lowland rainforest uccession in Costa Rica, Central America. Oecologia 61:99-104

Sanchez P (1976) Properties and management of soils in the tropics. Wiley, New York

Sauer W (1971) Geologie von Ecuador. Beiträge zur regionalen Geologie der Erde, Band 11. Bornträger, Berlin

Schawe M, Glatzel S, Gerold G (2007) Soil development along an altitudinal transect in a Bolivian tropical montane rainforest: podzolization vs. hydromorphy. Catena 69:83-90

Schuur E (2001) The effect of water on decomposition dynamics in mesic to wet Hawaiian montane forests. Ecosystems 4:259-273

Sibbesen E (1977) A simple ion-exchange resin procedure for extracting plant-available elements from soil. Plant Soil 46:665-669

Sveinbjörnsson B (2000) North American and European treelines: external forces and internal processes controlling position. Ambio 29:388-395

Sveinbjörnsson B, Davis J, Abadie W, Butler A (1995) Soil carbon rind nitrogen mineralization at different elevations in the Chugach Mountains of south-central Alaska, USA. Arct Alp Res 27:29-37

Tanner EVJ (1981) The decomposition of leaf litter in Jamaican montane rain forests. J Ecol 69:263-273

Tanner EVJ, Kapos V, Freskos S, Healey J, Theobald A (1990) Nitrogen and phosphorus fertilization of Jamaican montane forest trees. J Trop Ecol 6:231-238 
Tanner EVJ, Kapos V, Franco W (1992) Nitrogen and Phosphorus fertilization effects on Venezuelan montane forest trunk growth and litterfall. Ecology 73:7886

Tiessen H, Chacon P, Cuevas E (1994) Phosphorus and nitrogen status in soils and vegetation along a toposequence of dystrophic rainforests on the upper Rio Negro. Oecologia 99:145-150

Timoney K (1995) Tree and tundra cover anomalies in the subarctic forest tundra of northwest Canada. Arctic 48:1321

Uehara G, Gillman G (1981) The Mineralogy, Chemistry, and Physics of Tropical Soils with Variable Charge Clays. Westview Press, Boulder

Vitousek PM (1984) Litterfall, nutrient cycling, and nutrient limitation in tropical forests. Ecology 65:285298
Vitousek PM, Denslow JS (1986) Nitrogen and phosphorus availability in treefall gaps of a lowland tropical rainforest. J Ecol 74:1167-1178

Vitousek PM, Sanford RL (1986) Nutrient cycling in moist tropical forest. Ann Rev Ecol Syst 17:137-167

Vitousek PM, Porder S, Houlton BZ, Chadwick OA (2010) Terrestrial phosphorus limitation: mechanisms, implications, and nitrogen-phosphorus interactions. Ecol Appl 20:5-15

Walker TW, Syers JK (1976) The fate of phosphorus during pedogenesis. Geoderma 15:1-19

Wilcke W, Yasin S, Abramowski U, Valarezo C, Zech W (2002) Nutrient storage and turnover in organic layers under tropical montane rain forest in Ecuador. Eur J Soil Sci 53:15-27

Wilcke W, Oelmann Y, Schmitt A, Valarezo C, Zech W, Horneier J (2008) Soil properties and tree growth along an altitudinal transect in Ecuadorian tropical montane forest. J Plant Nutr Soil Sci 171:220-230 